\title{
Low-Frequency Interactions between the Summer Monsoon and the Northern Hemisphere Westerlies
}

\author{
By Tetsuzo Yasunari \\ Institute. of Geosience, University of Tsukuba, Sakura-mura, Ibaraki 305, Japan \\ (Manuscript received 13 January 1986, in revised form 19 August 1986)
}

\begin{abstract}
Inter-correlations between the active/break cycles of Indian summer monsoon and the circulation change in the northern middle and high latitude westerlies are investigated particularly relevant to the low frequency (30-50 day period) mode.

Empirical orthogonal functions and composite analysis revealed the standing-type east-west oscillations of the geopotential height field between central and far-east Asia with the node over Tibet.

Lag-correlations between the monsoon trough and the $500 \mathrm{mb}$ heights in the northern hemisphere suggest that this east-west oscillation is part of the response of the mid-latitude westerlies to the northward-moving monsoon heat source. The response in the higher latitudes seems to reach its maximum when the heat source approaches to the southern periphery of the westerlies; i.e., near to the break phase of monsoon.

A plausible mechanism of this interaction between the monsoon and the westerly flow in the higher latitudes are also briefly discussed.
\end{abstract}

\section{Introduction}

It has been well recognized now that the summer monsoon over India shows the active/ break cycle with the time scale of about 40 days as a major intraseasonal fluctuations (Yasunari, 1979, 1980, 1981; Krishnamurti and Subrahmanyam, 1982; Murakami, 1984, Murakami et al., 1984 etc.). The spatial structure of this mode consists of the prominent characteristics as follows:

1. The area of the maximum (minimum) cloudiness (or rainfall) gradually shifts northward from the equator to the Himalayan region with the phase speed of $0.5-1.0$ degree lat. day ${ }^{-1}$. The first northward shift of the maximum cloudiness may correspond with the onset of the monsoon. The meridional space scale is about 30 degrees in latitudes.

2. The area of the maximum (minimum) cloudiness has a zonally oriented band structure with the scale of 80-90 degrees in longitudes.

3. Anomalous cyclonic (anticyclonic) circulation is dominant especially in the lower-half of the troposphere associated with the maximum (minimum) cloudiness. In the upper troposphere, in contrast, the strength of the easterly wind changes related to the maximum/minimum overturnings of the cloudiness over central India.

These features imply that the monsoon fluctuation of this mode is part of a periodical northward shift of ITCZ over India through the western Pacific region. Furthermore, it was suggested (Yasunari, 1979; Julian and Madden, 1981) that the active/break cycle of this mode may be closely associated with the eastward propagating large-scale wave disturbance along the equator discovered by Madden and Julian (1971, 1972). Some recent studies (Lorenc, 1984, Krishnamurti et al., 1984, Murakami and Nakazawa, 1985 etc.) have confirmed these observational aspects by using FGGE/MONEX data set.

On the other hand, many studies (Ramaswamy, 1962; Kalsi, 1980; Pant, 1983 etc.) suggested that the active/break cycle of summer monsoon is closely related to the mid-latitude westerly 
wave movements in the northern hemisphere. For example, Ramaswamy (1962) pointed out that the break monsoon occurs when a deep westerly trough penetrates over the Indian subcontinent associated with the low-index circulation over central Asia. Some other studies (Raman, 1981; Tanaka, 1983 etc.) emphasized the role of blocking highs over central Asia to the west of Tibet as a signal of the break monsoon over central India.

Another interesting problem especially for the meteorologists in the eastern Asia is the inter-relations between the monsoon over India and the frontal rain over eastern Asia called "Baiu" in Japan or "Meiyu" in China. Asakura (1955) first pointed out that the onset date of the monsoon over southern India and that of the Baiu in Tokyo is positively correlated each other, although the data he used was only 15 years. Recently, Krishnamurti and Subrahmanyam (1982) suggested that circulation anomalies at $850 \mathrm{mb}$ over India is coupled with those over the eastern Asia through the Western Pacific
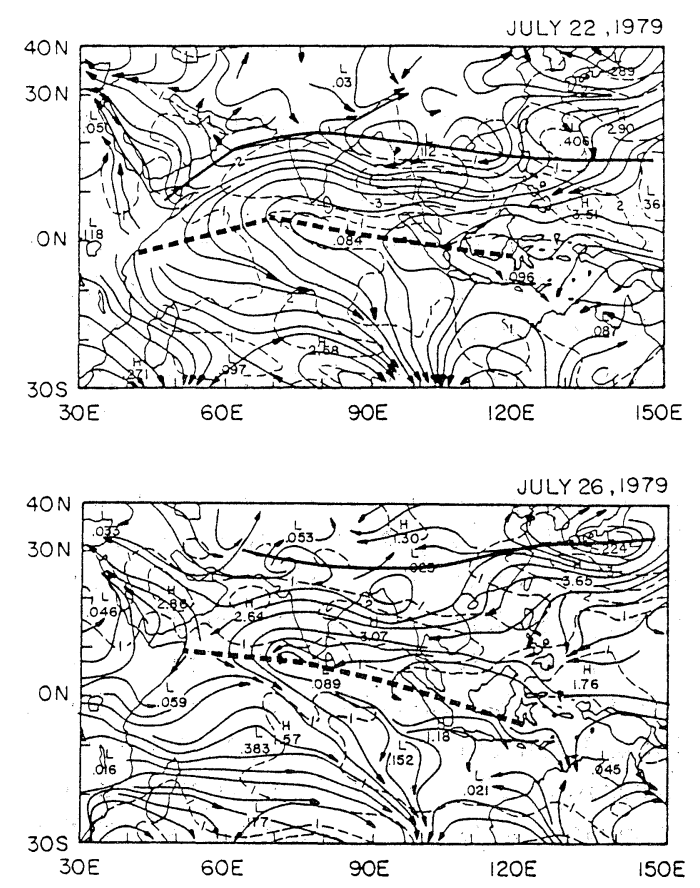

Fig. 1 Streamlines (solid lines) and isotachs (dashed lines) of the filtered wind for the 30-50 day period. Trough (ridge) axis is indicated with thick dashed (solid) lines. (after Krishnamuri and Subrahhmanyam, 1982) via the zonally oriented anomaly trough or ridge line which is moving northward. Fig. 1 shows, for example, a typical case of this east-west coupling. The anomaly ridge (solid line) exists over northern India through the western Pacific just to the south of Japan, while the anomaly trough (dashed line) exists to the south of India through Indonesia. Synoptically, this situation corresponds with the recovering stage of monsoon in southern India following the break monsoon over central India. Simultaneously, the Baiu season is ending over southern Japan associated with the strengthening of the Pacific high. They showed many other coupling phenomena similar to this through the whole monsoon period.

We note here that there are two contradictory interpretations on the mechanism of the active/ break overturnings of monsoon over India. One idea demonstrates the role of the planetary scale disturbance along the equator (i.e., the influence from the south), while the other stresses the role of the mid-latitude westerly waves (i.e., the influence from the north).

This study is directed toward a dissolution of this contradiction. For understanding the physical process of interaction between the low-frequency monsoon oscillation in the tropics and the westerly waves in the middle and high latitudes, we shall deduce some observational evidences in the regional as well as the hemispheric scale by applying some statiscal methods to pentad height field at $700 \mathrm{mb}$ and $500 \mathrm{mb}$ for 1965 to 73. A plausible dynamical process will also be discussed.

\section{Data}

The grid point data $\left(10^{\circ}\right.$ long. $\times 5^{\circ}$ lat.) of the pentad anomaly $700 \mathrm{mb}$ geopotential height over south Asia compiled by India Meteorological Department were used for the regional scale analysis. The northern hemisphere grid-point data $\left(10^{\circ}\right.$ long. $\times 10^{\circ}$ lat.) were adopted from the data set of Japan Meteorological Agency for the hemispheric analysis. Additionally, the pentad anomaly rainfall data for central India was used as an index of the monsoon activity. 


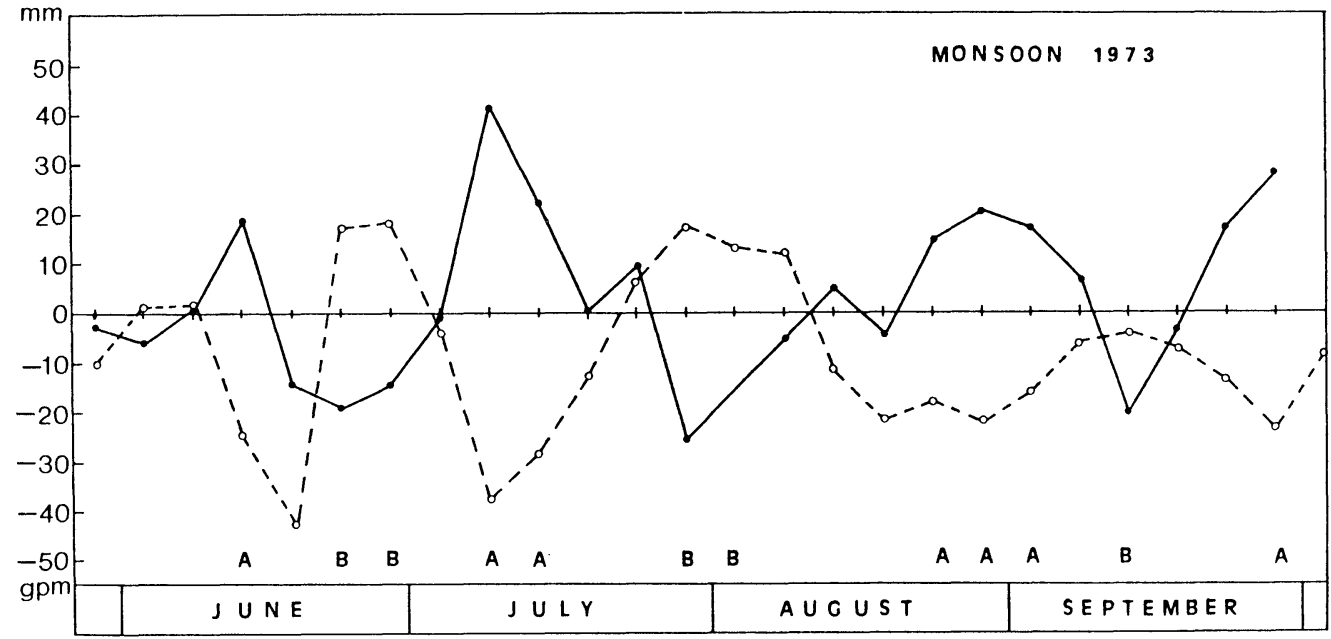

$-\infty-\infty \quad 700 \mathrm{mb}$ HEIGHT PENTAD ANOMALY (80E, 20-30 N)

Fig. 2 Pentad anomalies (from normal) of $700 \mathrm{mb}$ geopotential height over the monsoon trough (80E, 20$30 \mathrm{~N}$ ) and of rainfall over central India for the monsoon period of 1973. Active and break pentads are shown with $\mathrm{A}$ and $\mathrm{B}$ respectively.

3. The geopotential height patterns related to the active/break cycle of monsoon over India

It is well known that the monsoon trough in the lower troposphere oscillates with the monsoon activity over central India. The geopotential height at $700 \mathrm{mb}$ may be adequate to see the intensity of monsoon trough. For example, Fig. 2 shows the pentad anomalies (from normal) of rainfall over central India and those of the monsoon trough (geopotential height at $700 \mathrm{mb}$ ) for 1973 . The normal values published by Indian Meteorological Department are used here. The

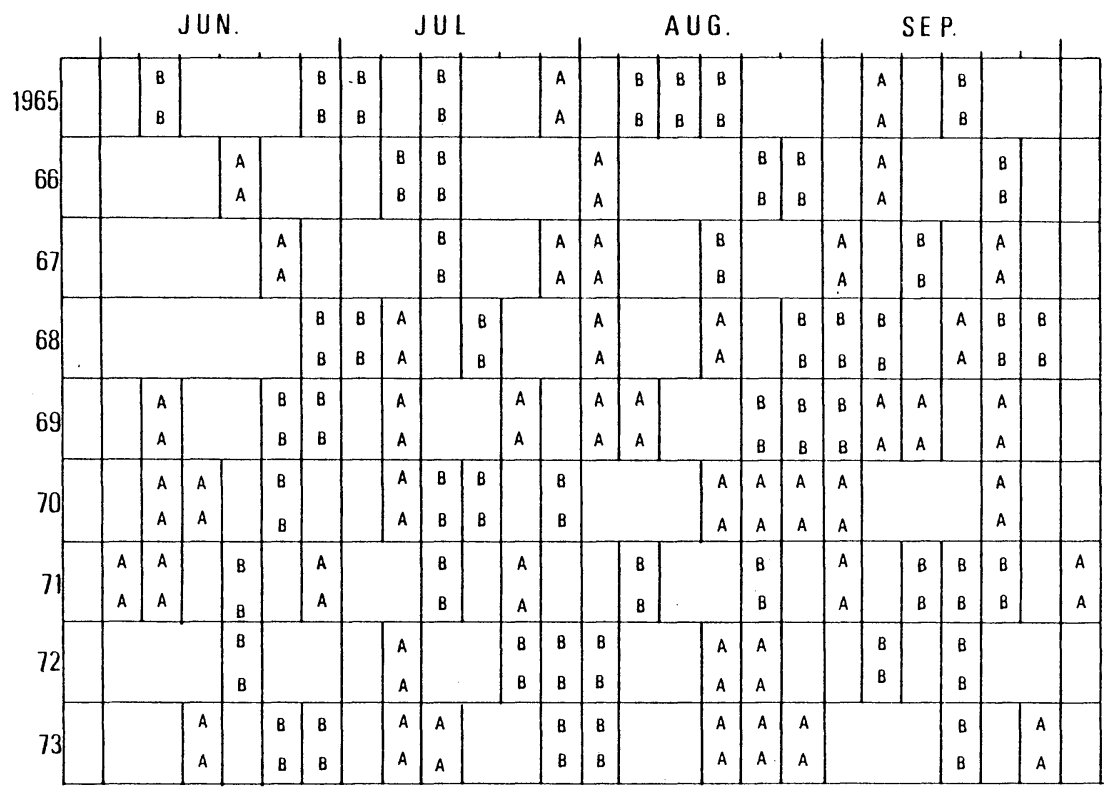

Fig. 3 Active (A) and break (B) pentads selected in this study. 
(a)

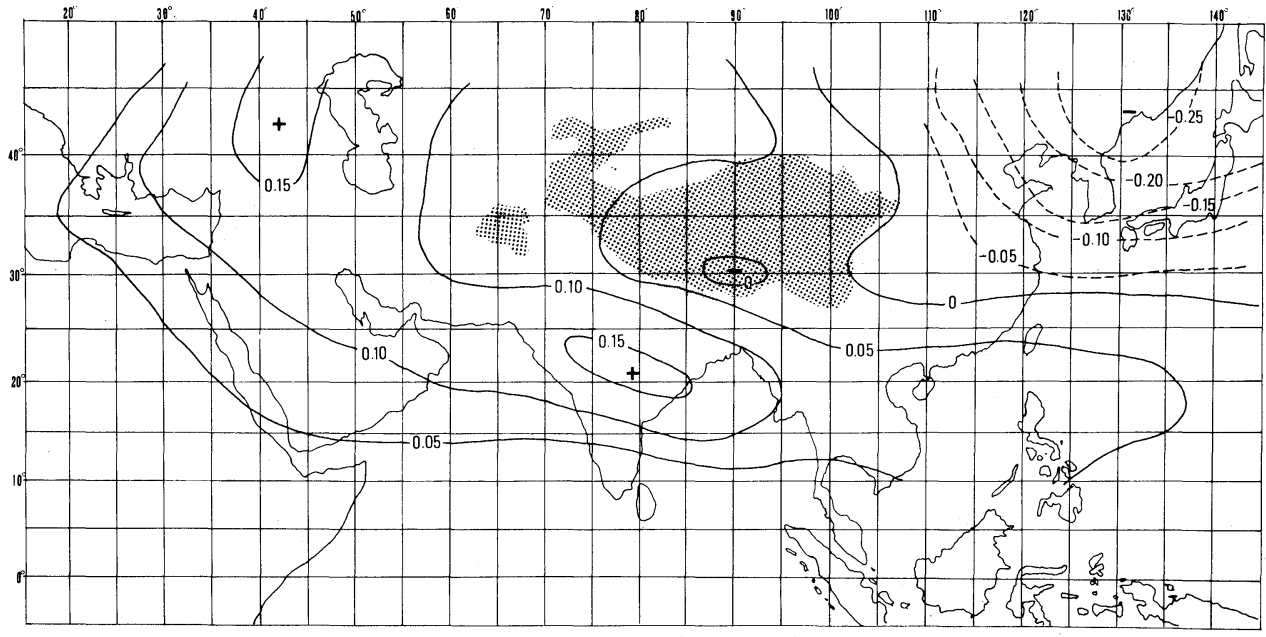

\section{$\operatorname{COMP}=2$}

(b)

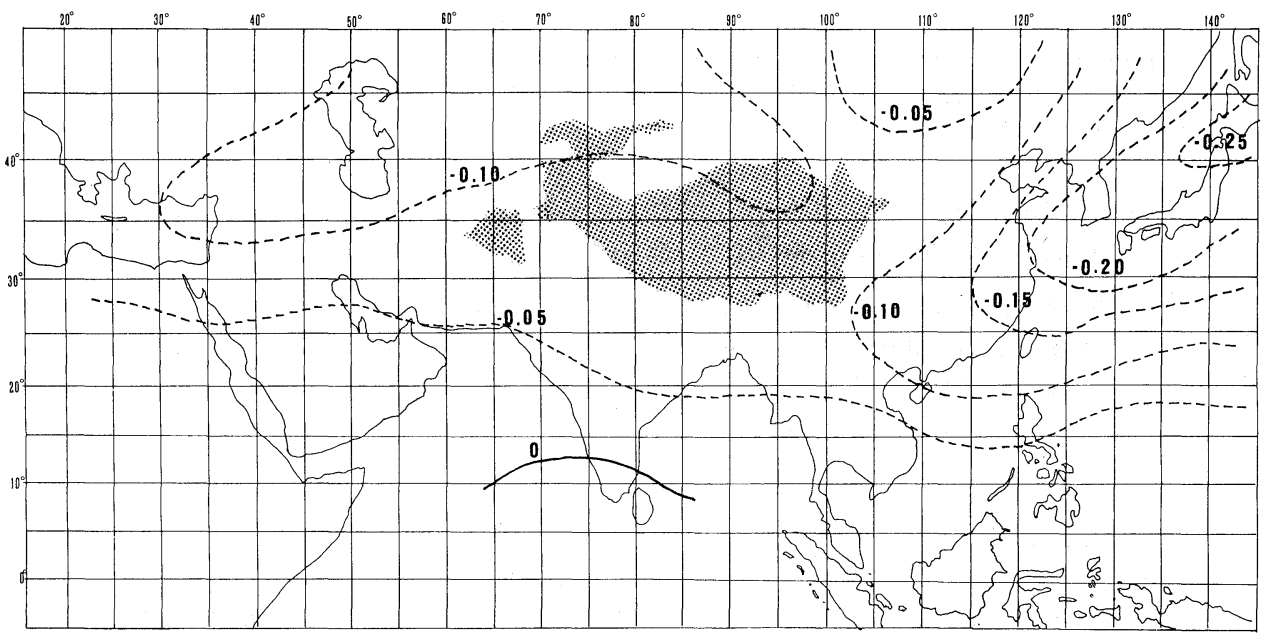

$\operatorname{COMP}=3$

(c)

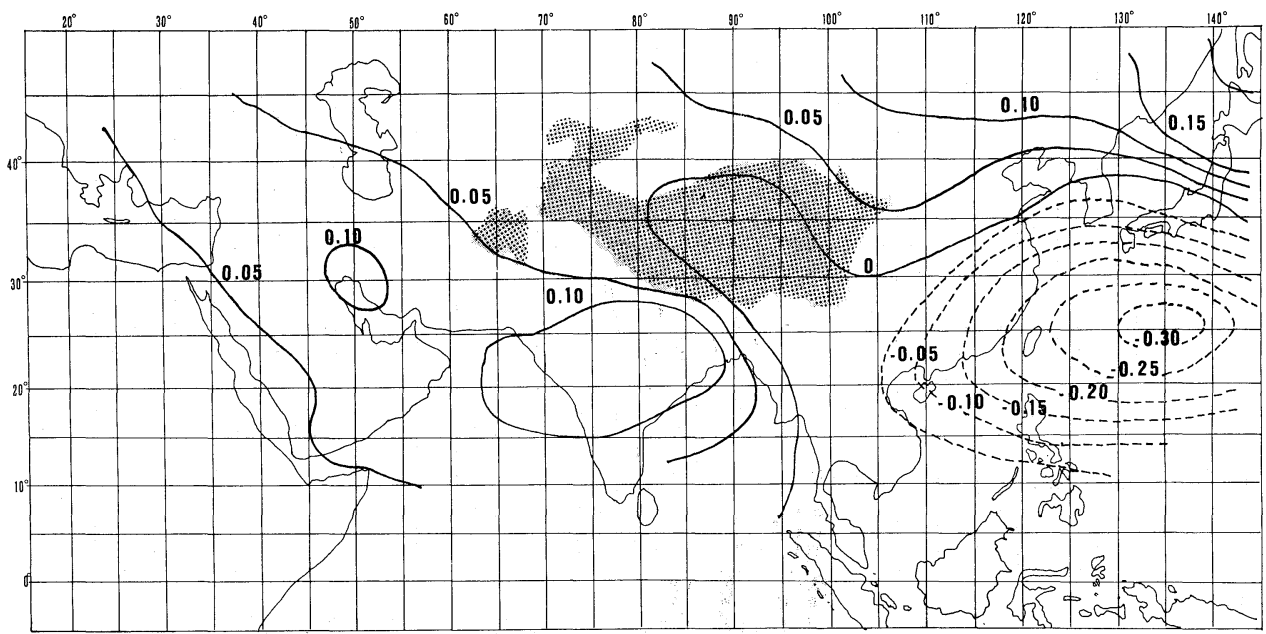


minimum or maximum of the height anomalies (dashed line) correspond well with the active or break phases, and is negatively correlated with the rainfall anomalies (solid line).

To deduce the dominant patterns of circulation change over a broader Asian monsoon region related to the oscillation of monsoon trough (or monsoon rainfall) over central India, about 50 pentads were selected respectively as typical active and break phases during the years from 1965 to 1973 as shown in Fig. 3. The total number of pentads is 96 .

The empirical orthogonal function (EOF) analysis was applied to the unnormalized pentad anomaly $700 \mathrm{mb}$ height for these selected pentads. The space area for this analysis covers the southern part of Asia in the square of $10 \mathrm{~N}-$ $45 \mathrm{~N}$ and $20 \mathrm{E}-145 \mathrm{E}$. The covariance matrix of 104 grid-points was diagonalized to yield the EOFs.

Fig. 4(a) shows the spatial pattern (eigenvectors) of the 1st component (which occupies about $23 \%$ of the total variance). This pattern clearly demonstrates high positive correlations between the height anomalies of the monsoon trough and central Asia near Caspian Sea, and high negative correlations between the monsoon trough and the eastern Asia near Japan and Korea. It may be preferable to say that the height anomalies show an standing oscillation between the two areas to the east and to the west of Tibetan Plateau.

Fig. 4(b) shows the spatial pattern of the 2nd component (19\% of the total variance). Negative eigenvectors are dominant over the whole region which implies that the height changes nearly simultaneously over this area associated with the active/break cycle of monsoon. We should note, however, the large negative values exist over the eastern Asia centered in Japan. Namely, this component may exhibit the pattern whose height changes related to the active/break cycle of monsoon are not large in situ (over monsoon trough) but very large over this area.

Fig. 4(c) shows the 3 rd component $(11 \%$ of the total variance), which again expresses a strong negative correlation between the monsoon trough anomalies and the height anomalies over the eastern Asia through the western Pacific. This pattern may represent a strong negative correlation between the developments of typhoon or tropical depressions in the western Pacific to the south of Japan and the monsoon activity over India as pointed out by Tanaka (1983).

It is noteworthly to state that all the three major components (which explain about 53\% of the total variance) show that the active/break cycle of monsoon is a phenomenon strongly connected with the circulation changes in the mid-latitudes to the east and to the west (more strongly to the east) of Tibetan Plateau. This may be a clear evidence of the interaction between the monsoon circulation and the westerly waves in the mid-latitudes. Recently, Lau and Chan (1986) found a dipole pattern in outgoing longwave radiation (OLR) anomalies over India

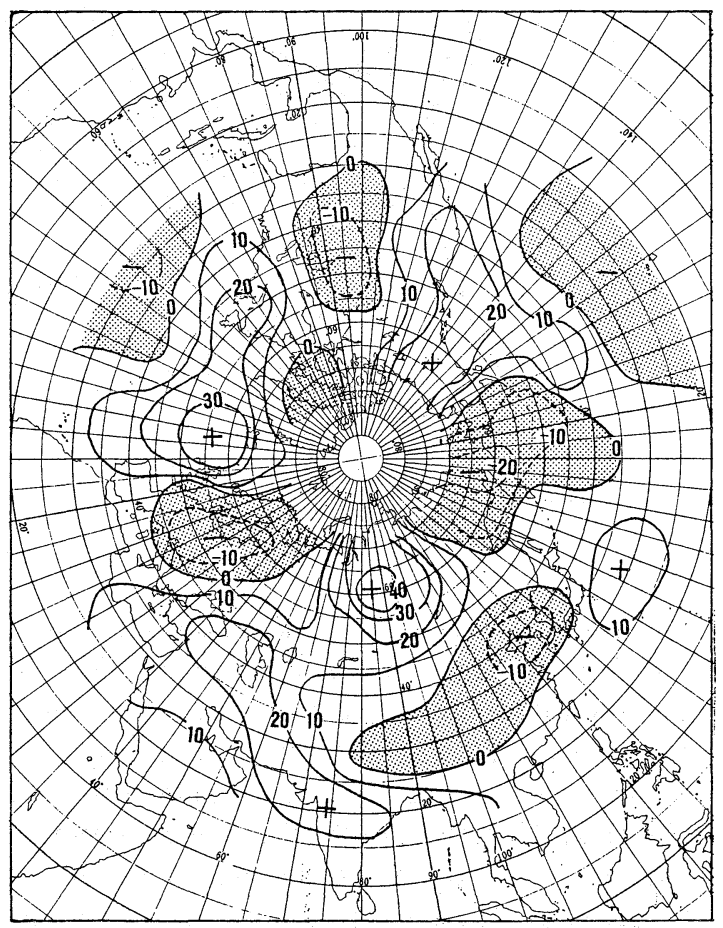

Fig. 5 Composite anomaly chart of $500 \mathrm{mb}$ geopotential height by subtracting the averaged height for the active period from that for the break period of monsoon over central India. Negative values are shaded. (Units: gpm)

Fig. 4 Spatial patterns of the (a) $1 \mathrm{st}_{2}$ (b) 2 nd and (c) 3rd component of EOFs for 700 mb pentad anomaly geopotential height deduced from the data of 96 active and break pentads. 


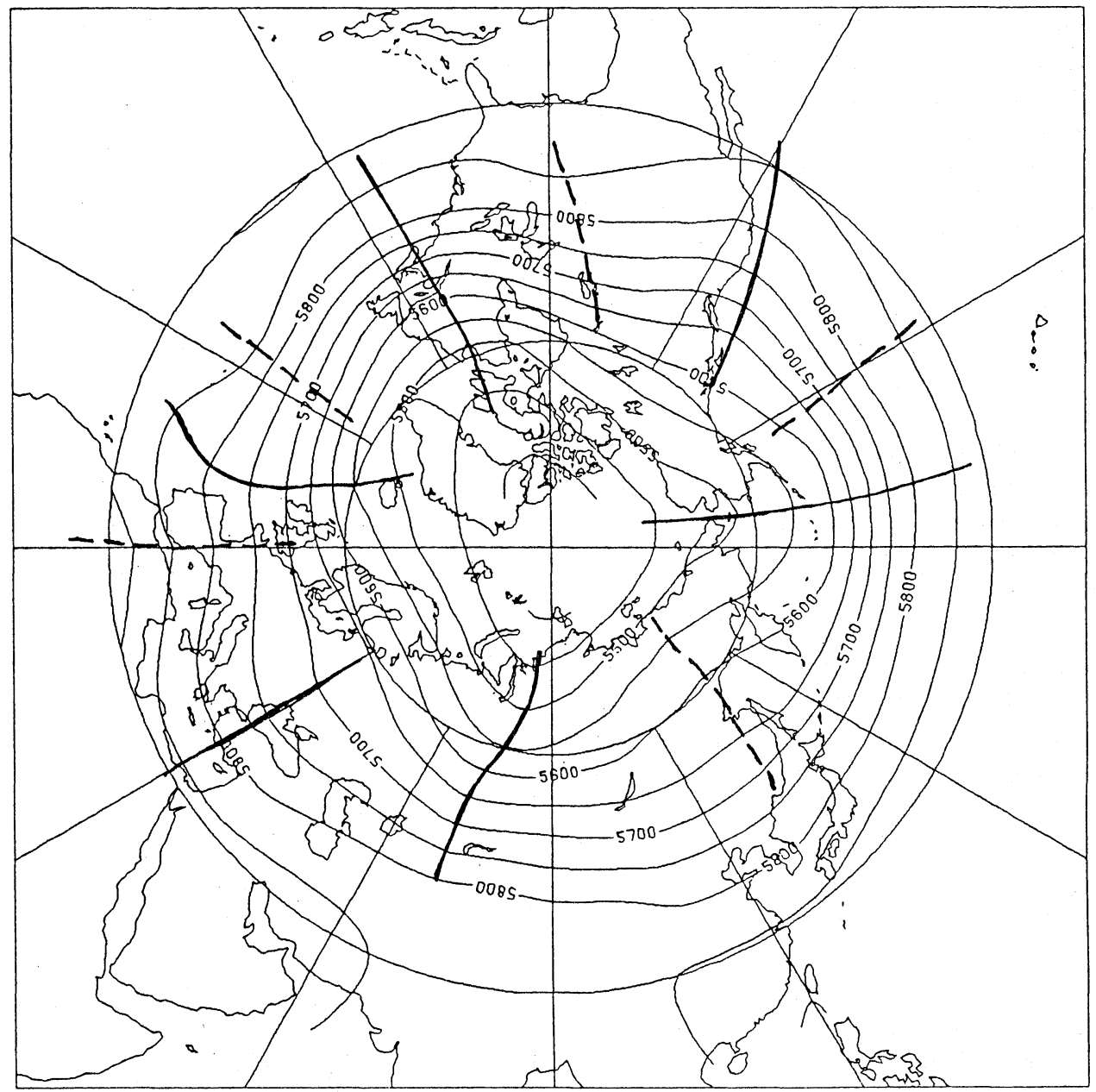

(a)

through the western Pacific associated with this low-frequency mode in summer. That is, when OLR anomalies are negative (i.e., more cloudiness) over India, those over the western Pacific are positive (i.e., less cloudiness) and vice versa. Hirasawa (1986) also noted the similar relations in OLR and geopotential field during FGGE year. These results seem to be consistent with the EOF results here.

The aforementioned results showed the dominant circulation patterns associated with the low frequency mode of monsoon for the limited area over southern Asia. Hereafter, we examine the height anomaly patterns over the whole northern hemisphere. The grid-points data for the $500 \mathrm{mb}$ pentad anomaly geopotential height is used for the same years (19651973). Since the total number of grid-points are too large to apply the EOF analysis by our computer, the anomaly composite map was produced.

Fig. 5 shows the anomaly composite map deduced from the average height for the 50 break pentads by subtracting that for the 46 active pentads. The anomaly pattern over southern Asia is very similar to the spatial pattern in Fig. 4(a), which may imply that the height anomaly contrast between the two areas to the west and the east of Tibet is really a dominant pattern related to the major active/break cycle 


\section{COMPOSITE 500 MB HEIGHT FIELD ( CASE B)}

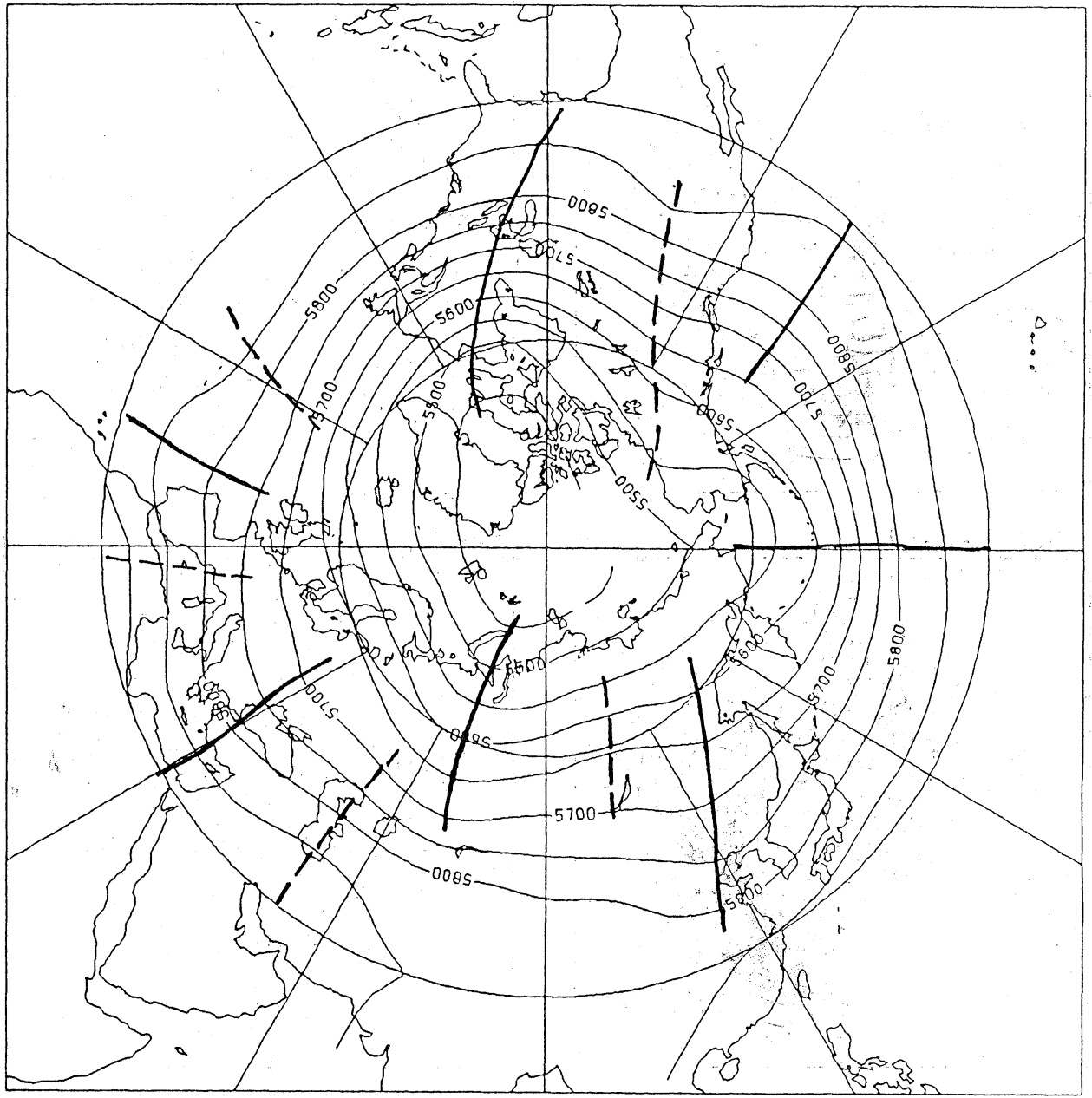

(b)

Fig. 6 Composite chart of $500 \mathrm{mb}$ geopotential height for (a) active pentad and (b) break pentad. Trough and ridge are indicated with solid and dashed lines, respectively. Unit of contour is $50 \mathrm{gpm}$.

of monsoon over India. Although the circulation anomalies in the middle and high latitudes may be greatly different from year to year and month to month, the composite map shows a quite systematic pattern as a whole. Three areas of large positive and negative height anomalies are prominent, which appear alternately in the latitudes between $40 \mathrm{~N}$ and $70 \mathrm{~N}$. Fig. 6 shows real geopotential height fields at $500 \mathrm{mb}$ composited for (a) active and (b) break pentads. It can easily be seen that considerable changes of stationary trough-ridge positions appear between the two phases particularly over Asia, the north- ern Pacific and Norh America. Over Asia a deep trough is located at about $70 \mathrm{E}$ and a prominent ridge exists over Far East $(130 \mathrm{E}-140 \mathrm{E})$ at the active phase, while at the break phase a ridge appears over Caspian Sea (50E) and an elongated trough appears over northeast Siberia through central China. Namely, the anomalous pattern over Asia shown in Fig. 5 represents the difference of real trough-ridge pattern between the active and break phases. A large difference in trough-ridge position - is also noted over the north Pacific through north America between the two phases, but a little difference over the 


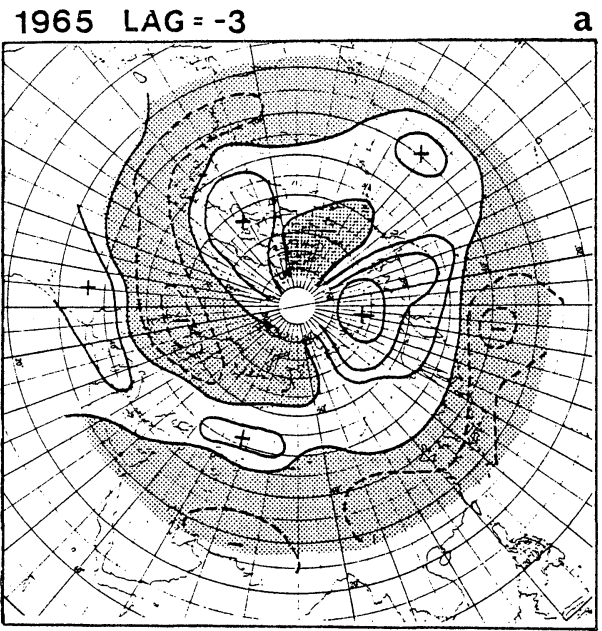

$1965 \mathrm{LAG}=-2$
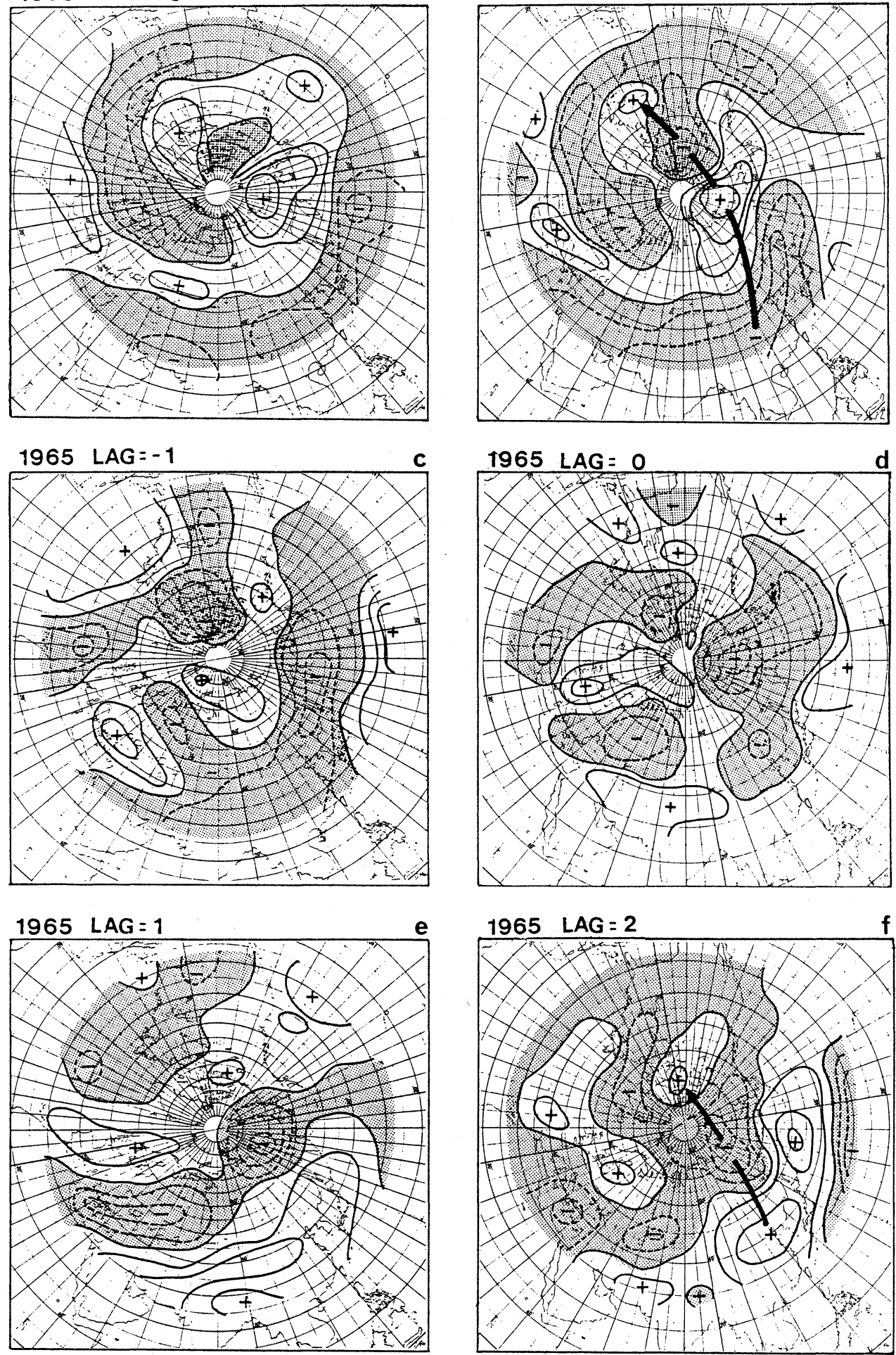
Atlantic through Europe.

\section{Lag-correlations between the active/break cycle of monsoon and the geopotential height over the northern hemisphere}

It was suggested in the previous section that the active/break cycle of monsoon is associated with the hemispheric changes of circulation pattern. However, the inter-relations between the two systems in the time sequence are not clear by the EOF analysis and the simultaneous correlations. It may also be true that the interrelations may depend on the mean monthly or seasonal flow pattern for each year. Accordingly, the time-lag correlations between the monsoon trough and the geopotential height field over the northern hemisphere were calculated for each year, to see how the circulation pattern changes in the course of the transition of monsoon activity over central India. As an index of monsoon trough intensity, the pentad anomaly $700 \mathrm{mb}$ geopotential height was again adopted by averaging the two grid-points data over central India. The $500 \mathrm{mb}$ pentad anomaly geopotential height was used as a measure of the circulation patterns in the mid-troposphere.

Fig. 7 shows the time-lag correlation maps from LAG $=-3$ pentad (the correlations between the monsoon trough intensity and the geopotential height of 3 pentads before) to LAG $=+2$ pentad for the monsoon period (June to September) of 1965. It may become more easier to understand these patterns if we consider the map for $\mathrm{LAG}=-3$, for example, as a kind of composite height anomaly chart for the period 3 pentads before the maximum height at the monsoon trough (namely, the maximum stage of break monsoon over India). Additionally, if we take account of the time scale of one active/break cycle (6 to 10 pentads) of this low frequency mode, this map may exhibit the height anomaly distribution at or just after the most active phase of monsoon over central India. Similarly, the map for LAG $=0$ may correspond with the composite height anomalies at the maximum stage of break monsoon over India.

Fig. 7(a) shows a broad area of negative coefficients over the monsoon trough area through the western Pacific, and a broad area of positive coefficients to the north of it. The area of large positive coefficients is prominent over northeast Siberia through the Aleutian islands. This pattern suggests the negative correlation between the monsoon trough and the Okhotsk high as formerly pointed out by Asakura (1955) and Suda and Asakura (1955).

At $\mathrm{LAG}=-2$ (Fig. 7(b)), negative values become larger especially over eastern Asia, while the area of positive values to the north of it also becomes more prominent. This implies that the contrast of negative-positive values is intensified over Far East Asia to the north of Japan. The mutually existing large negativepositive values along the great circle from east Asia, northeast Siberia through the north America (as shown with a solid line) seems to appear as a Rossby wave train as a response to thermal or dynamical forcing over eastern Asia. This feature seems to suggest that the circulation change in the middle and high latitudes is at least partly a response to the monsoon heat source over Asia. We will discuss further on this problem in section 5. The area of positive values is also prominent over southern Europe. At higher latitudes to the north of $50 \mathrm{~N}$, the correlation pattern seems to be wavenumber 3 type as a whole.

We should recall here that the anomaly monsoon trough gradually shifts northward to the Himalayas during the course from active to break phase over central India. Namely, the correlation pattern seems to become more distinct when the monsoonal convective activity shifts northward from central India to the Himalaya region.

At $\mathrm{LAG}=-1($ Fig. $7(\mathrm{c}))$, the whole pattern resembles that of $\mathrm{LAG}=-2$, but becomes less systematic compared to $\mathrm{LAG}=-2$. The areas of negative values over Far East shifts more

Fig. 7 Lag correlations of pentad anomaly geopotential height $(500 \mathrm{mb})$ with pentad anomaly monsoon trough $(700 \mathrm{mb})$ during 1965 summer for the lags of -3 through +2 pentads. Units of contour are 0.2 and negative values are shaded. Supposed Rossby-wave responses are shown with thick solid lines. 
eastward and the positive-anomaly area over southern Europe also shifts eastward to central Asia. This feature over central Asia may be identified as the appearance of blocking highs as a precursor of the break monsoon over central India, whose anomaly pattern is shown in the next figure (Fig. 7(d)) for LAG $=0$.

In Fig. 7(d), the pattern over monsoon Asia is very similar to that of Fig. 5, although the pattern over the other area shows somewhat different from it. The area of positive values over central Asia in Fig. 7(c) moved eastward to the northwest of India.

At $\mathrm{LAG}=1$ (Fig. 7(e)), the broad area of positive values expand toward eastern Asia with large contrast to the north of it. The whole pattern can be compared to that of $\mathrm{LAG}=-2$. These two patterns appear quite similar each other opposite signs.

The pattern of LAG $=2$ (Fig. $7(\mathrm{f})$ ) is nearly identical with that for $\mathrm{LAG}=-1$ or $\mathrm{LAG}=-2$ but with the opposite sign. This may imply that the anomaly circulation pattern over the whole of the northern hemisphere changes almost cyclicly with the period of 6 to 8 pentads ( 30 to 40 days) associated with the active/break cycle of monsoon over India through southeast
Asia.

To examine the difference of the correlation patterns among latitude bands more precisely, the (pentad) lag-longitude sections for $80 \mathrm{~N}$, $60 \mathrm{~N}$, and $40 \mathrm{~N}$ were produced as shown in Fig. 8 . At $40 \mathrm{~N}$ (Fig. 8(c)), it is clearly demonstrated that the pattern of large positive and negative correlations to the west and the east of Tibet is reversed values. The area of large coefficient values is limited in the eastern hemisphere. It should be noted that the maximum (or minimum) coefficient values are prominent not at $\mathrm{LAG}=0$ but at $\mathrm{LAG}=+1$ or +2 .

At $60 \mathrm{~N}$ (Fig. 8(b)), the whole pattern resembles wavenumber 3 with the eastward movement. Although the absolute values of the coefficients are not so large as a whole, the maximum (or minimum) values seem to appear at $\mathrm{LAG}=+2$ or +3 .

At $80 \mathrm{~N}$ (Fig. 8(a)), in contrast, the whole pattern seems to correspond with the oscillation of standing wave of wavenumber 1 with the maximum and minimum values at around the date-line. It is noteworthly to state that the correlations there with the monsoon activity are larger than those of the mid-latitudes $(60 \mathrm{~N})$ and that the maximum (or minimum) values

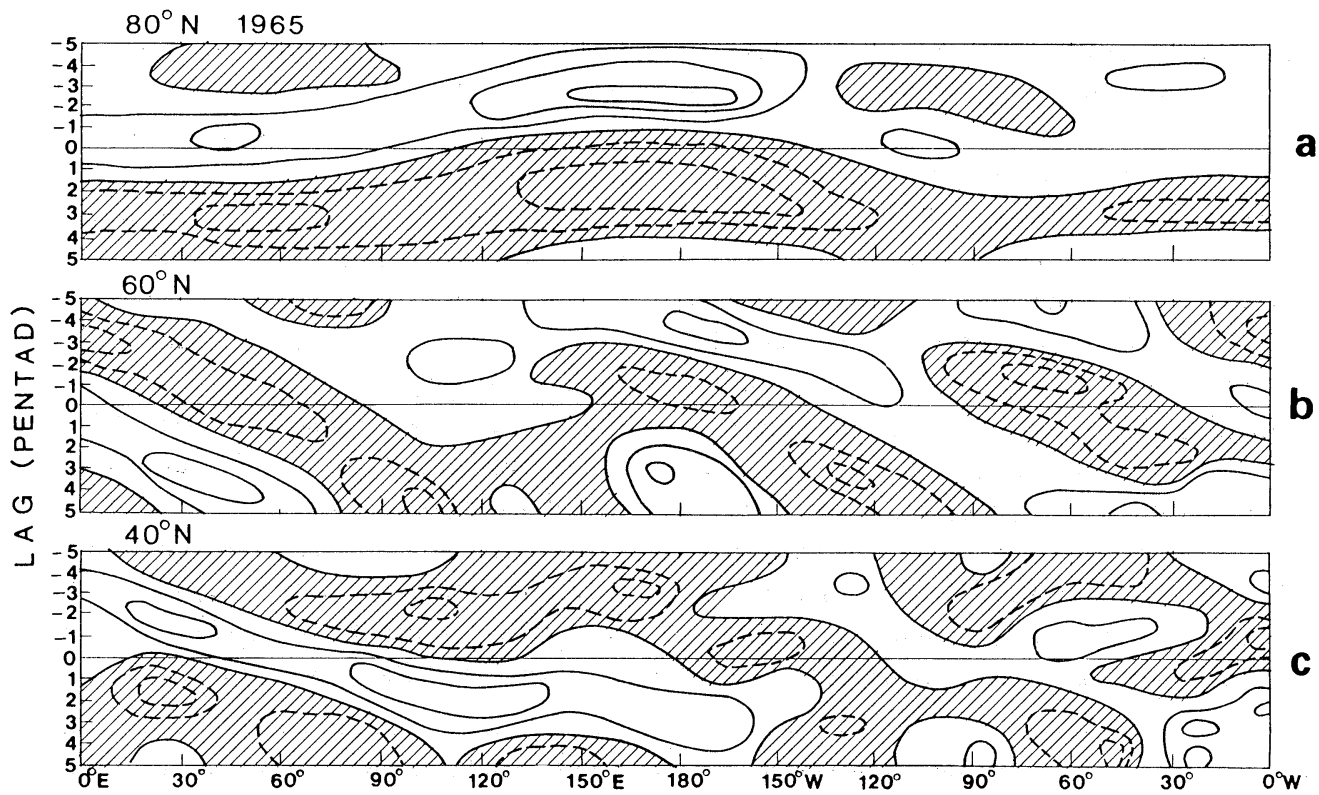

Fig. 8 Time lag (in pentad) - latitude sections of correlation coefficients for (a) $80 \mathrm{~N}$, (b) $60 \mathrm{~N}$ and (c) $40 \mathrm{~N}$ reproduced from Fig. 5. Units are 0.2 and negative values are shaded. 
exist again at around $\mathrm{LAG}=+2$.

The results mentioned above were derived from the case study for 1965 . We made similar analyses for 9 years from 1965 to 1973. The correlation pattern differs considerably from year to year especially over the mid-latitudes $(50 \mathrm{~N}-60 \mathrm{~N})$. However, for most of the years the patterns over south Asia through the western Pacific to the south of $40 \mathrm{~N}$ showed more or less similar features to the case for 1965. Moreover, in most of the years the pattern of standing wave of wavenumber 1 was dominant over the high latitudes $(70 \mathrm{~N}-80 \mathrm{~N})$ with somewhat large coefficient values at the maximum (or minimum).

\section{Discussion}

We showed in this paper some statistical relations between the active/break cycle of monsoon over India and the westerly flow patterns in middle and high latitudes associated with the low frequency mode. One of the central problems may be whether the monsoon acts as a forcing to the westerlies or the monsoon fluctuates in response to the westerlies. In other words, we have to see how the dynamical process occurs between these two circulation systems in the time sequence of the interaction. Unfortunately, the lag-correlation analysis did not make it so clear which system precedes dynamically to the other, since the fluctuation of both systems appeared as nearly cyclic with the periodicity of 6 to 8 pentads (30-40 days).

Some dynamical studies were already done on the 40-day mode oscillation of monsoon system (e.g., Chang, 1977; Stevens, 1983; Yamagata and Hayashi, 1984 etc.), although these studies have revealed the mechanism of only some aspects of this mode. Whatever the mechanisms, the oscillation of monsoon of this mode may be related to the thermal and dynamical forcing around the equator or possibly in the southern hemisphere, if we take account of the meridional phase propagation of this mode from the equator to the mid-latitude.

On the other hand, we should not the prominent observational aspects shown in this paper. That is, the negative (positive) height anomalies change rapidly from the west to the east of Tibet when the negative (or positive) anomaly mon- soon trough shift northward to the Himalayas, and at this time the correlation (whether it is positive or negative) between the monsoon trough intensity and the geopotential height anomalies in the middle and high latitudes reaches its maximum. In their detailed stream line analysis at $850 \mathrm{mb}$ (refer to Fig. 1), Krishnamurti and Subrahmanyam (1982) showed that the anomaly trough (or ridge) lines of this low frequency mode suddenly jump northward at its east end (in the western Pacific near Japan) when these lines over southern Asia reached the Himalaya-Tibet region as clearly shown in Fig. 1 (lower). This may certainly be a synoptic evidence for the statistical results mentioned above.

The observational evidences shown here may suggest that the circulation pattern changes in the middle and high latitudes described here is at least partly a response of the northward migrating anomalous monsoon heat source when it reaches the southern periphery of the westerly zone. Some considerations on the dynamical process are presented in the following.

It has been demonstrated by Hoskins and Karoly (1981) and Webster $(1981,1982)$ that the response of the atmosphere to the heat source changes largely and drastically depending on the location of the heat source in latitudes as well as the basic flow distribution on it. Hoskins and Karoly (1981) introduced a nondimensional value as follows:

$$
\gamma=\frac{f^{2}[\bar{u}]}{\beta N^{2} H_{Q} H}
$$

where $[\bar{u}]$ is the time and zonal mean $u$-component, $N$ is Brunt-Väisälä frequency, $H_{Q}$ is the vertical scale of the diabatic heating, $H=\min \left(H_{Q}\right.$, $\left.H_{u}\right) . H$ is the vertical scale of the zonal wind. This $\gamma$ is a parameter for comparing the size of the horizontal advection and the vertical advection (adiabatic cooling) in the thermodynamic equation. If $\gamma<<1$, a balance of direct circulation is dominant, where the vertical advection term and the diabatic heating term is nearly balanced. If $\gamma>>1$, an indirect circulation is dominant, where the horizontal advection term is nearly balanced with the diabatic heating term. Webster (1981) named the former balance "diabatic 
limit" and the latter "advective limit". Remote response (or "teleconnection") is more feasible in the balance of "diabatic limit", since the available potential energy easily increases and maintains in this process. In the balance of "advective limit", local response is possible, though the persistence of this response may be, in many cases, weak because of the weakening or removing of the heat source itself by the effect of horizontal advection.

As we can see easily from this formula, in the low latitudes where $\beta$ is large and $f$ is small "diabatic limit" is most feasible and dominant, and in the higher latitudes "advective limit" may be common. However, as precisely discussed by Webster (1982), "diabatic limit" may occur, or rather the intermediate stage between these two balance may be dominant in the mid-latitude summer where $[\bar{u}]$ is generally very weak.

The difference of the circulation pattern around the heat source may be quite contrastive between the two balances. If we assume a simple vorticity balance for a stationary or slowly moving large-scale waves, the trough in the lower level should be to the west of the heat source in the "diabatic limit", while in the "advective limit" the trough should be to the east of the heat source (Hoskins and Karoly, 1981) as schematically illustrated in Fig. 9.

In summer $500 \mathrm{mb}$ level may be considered as the lower troposphere at least in lower latitude to the south of $40-50 \mathrm{~N}$, while it may be considered as the upper troposphere to the north of 40-50N (White, 1982). Therefore, the appearance of the large negative (or positive) correlations over east Asia in Fig. 7(b) (or Fig. 7(e)) may indicate that the "advective limit" type response may take place when the anomaly monsoon trough approaches to the Himalaya.

In contrast, when the monsoon heat source is located over central India, the diabatic heat source by intensive cumulus convection may be balanced with the strong vertical motion, which in turn intensifies the monsoon circulation itself. Namely, the active phase of monsoon over central India may be considered as a balance of "diabatic limit". This may give at least partly an answer of why the center of the monsoon trough in the mean state is located to the west
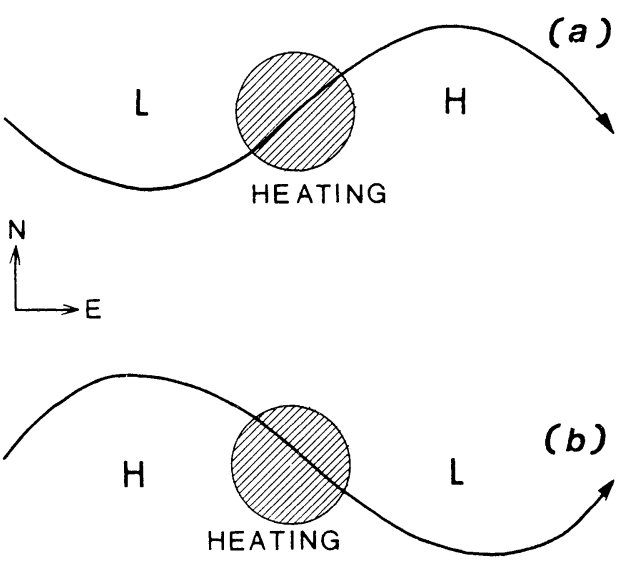

Fig. 9 Schematic flow patterns in the lower troposphere balanced with thermal forcing (shaded areas) in (a) "diabatic limit" and (b) "advective limit" based on Hoskins and Karoly (1981).

of the main rainfall area over south and southeast Asia. In this stage, however, the remote nor local response in the higher latitudes is strong as shown in Fig. 7(d) or Fig. 8. One reason for this is the existence of the easterly jet over the heat source region, which may prevent the propagation of wave energy to the westerly zone (Charney, 1963; Bennett and Young, 1971 etc.). The easterly wind is, as is well known, intensified in this stage, which may make the heat source further difficult to raise the response in the westerly zone.

Webster (1982) showed that the remote response possibly occurs even when the heat source is located in the tropical easterly zone. We should note, however, that the heat source prescribed in his numerical model was large enough to cover the southern periphery of the westerly zone even if the center of the heat source is located in the easterly zone. It may be true, in this sense, that the total response reaches its maximum when the center of the heat source is sifted to the boundary of the westerly and the easterly winds, which was also emphasized by Webster (1982).

However, a great difference between his model study and our observational study may be a nature of heat sources. His model premised the SST anomalies as an origin of heat source, while the monsoon heat source supposed here owe largely to the latent heating which is re- 
sulted purely from the dynamics of the monsoon circulation itself. This may imply that the heat source (cumulus convective activity) is actually weakened sometime after it reaches the southern boundary of the westerly wind because of the removing effect of heat by horizontal advection. That is, the balance of heat may easily tend from the "diabatic limit" to the "advective limit" type when the heat source reaches to the westerly zone (e.g. the region over the Himalaya through Tibet). The sudden shift of the negative geopotential anomalies from the west to the east of Tibet may be a clear evidence for this.

On the other hand, the weakening of the monsoon heat source results in the weakening or southward retreat of the upper easterlies, which may in turn make the heat source more feasible to force the Rossby wave response in the westerlies. Although the termodynamic balance is near to the "advective limit", this highly nonlinear process may be greatly responsible for the large correlation patterns at this stage in the middle and high latitudes as typically shown in Fig. 7(b), 7(e), and 7(f).

Although the discussion made here is qualitative, there are some supports of this hypothesis from the synoptic and dynamical points of view. Ramaswamy (1962) pointed out that at the active phase of monsoon the longitudes of India shows the separation of the lower monsoon westerlies and the upper middle westerlies, while these two westerlies are combined together at the break phase. Fig. 10 shows, for example, the latitude-height sections of the zonal wind averaged over the longitudes of India $(67.5 \mathrm{E}-$ 101.25E) for the typical phase of (a) active monsoon and (b) break monsoon over central India, deduced from FGGE III-b data set. Main heat source regions are also identified from the satellite-deduced distribution of net radiation convergence (Smith, 1984). We may postulate from this figure that the monsoon heat source is located in and around the mid-latitude westerlies only during the break or nearly-break phase of monsoon. In other words, the "window of interaction" between the monsoon and the mid-latitude westerlies seems to open only in or near the break phase (i.e., when the monsoon trough shifts to the Himalayan side). Recent

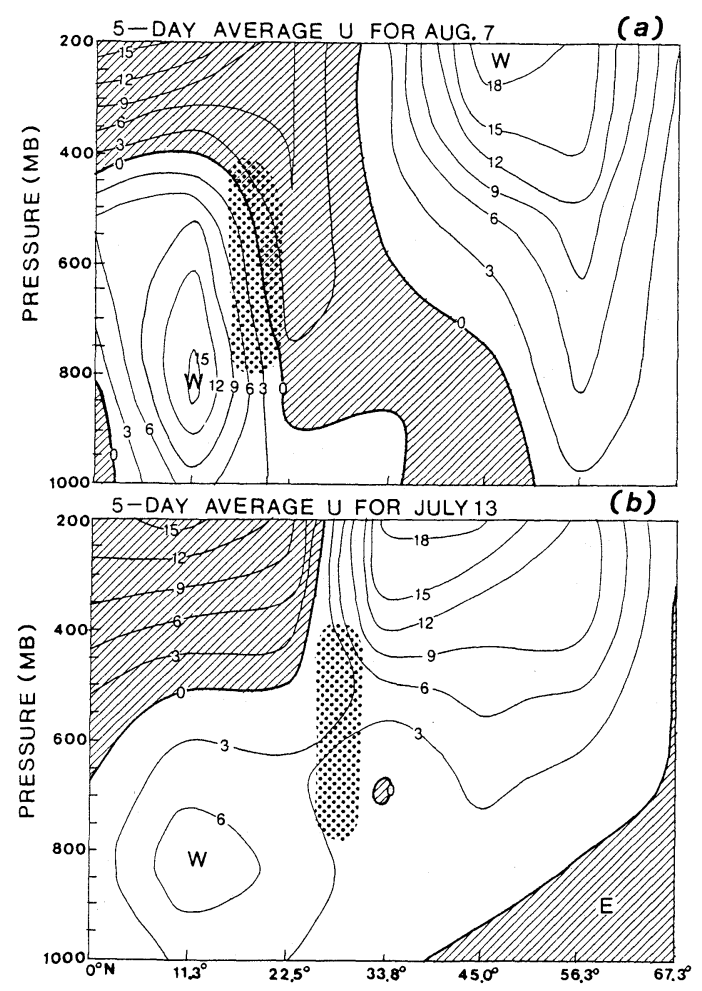

Fig. 10 Latitude-height section of zonal wind along the longitudes of India $(67.5 \mathrm{E}-101.25 \mathrm{E})$ for (a) active monsoon period (Aug. 5-9, 1979) and (b) break monsoon period (July 11-15, 1979) over central India. Easterlies are shaded and the presumed diabatic heat source regions (deduced from Smith (1984)) are also shown with hatched area. (Units: $\mathrm{ms}^{-1}$ )

numerical model studies (e.g., Lin, 1983; Huang, 1985; Kuma, 1985) also pertinently showed that only the forcing located in the mid-latitude westerlies can contribute the latitudinal propagation and interaction of waves among latitudes.

We can find some evidence for this hypothesis even in the papers stressing the influence of the mid-latitude westerlies to the monsoon. Pant (1983), for example, suggested that the deep westerly trough penetrating into Tibet-Himalaya region with cold air advection may have a great role to the break monsoon over India. He also pointed out by some energetic estimation that at the break phase over central India the poleward eddy heat flux reached its maximum and also the generation of available potential energy extremely went down over the continent to the 
north of India. This is exactly consistent with the characteristic feature of "advective limit" balance. It may be true that the break condition occurs more easily if the westerly trough migrates toward the Tibet-Himalaya region because of the strengthened horizontal advection. However, we may emphasize here that this effect (of the westerly trough) is valid only when the monsoon heat source have approached to this region. In other words, the cold air advection may not be a cause of the break monsoon but preferably the result of it.

Thus, we may conclude that the break monsoon over India is brought about and sustained as a result of the highly non-linear interaction of the westerly waves with the monsoon heat source approached to the southern margin of the westerlies.

Recently, Lau and Phillips (1986) showed that in winter the space/time evolution of extratropical wavetrains are coupled with the tropical dipolar convection in the manner that forcing-response relations change from place to plate depending on the location of heat source in the tropics. However in summer, the interaction between the tropics and mid-latitudes seems to be confined more over the Asian summer monsoon region because of more localized heat source area and the existence of broad area of the upper easterlies.

The remote response as suggested in Fig. 7 may possibly raised not only by heating over India but also by heating over a broader monsoon area including the western Pacific as noted by Kurihara and Tsuyuki (1986).

The maximum reduction of the heat source by the advection process may correspond with the maximum stage of monsoon break over central India, when the response in higher latitudes is also reduced. The sensible heating over Tibetan Plateau may contribute largely to the revival of monsoon circulation as discussed by Yeh and Gao (1979).

As pointed out already, the correlation patterns in higher latitudes are greatly different from year to year. This may be due to large difference of response depending on the basic zonal flow characteristics of each year as suggests by Lin (1983).

\section{Summary}

This paper presented some statistical results of significant inter-correlations between the active/break cycle of summer monsoon over India and the circulation patterns in the higher latitudes especially relevant to the low frequency (30-50 day period) mode.

The oscillation of monsoon system of this mode is closely connected with the east-west oscillation of the geopotential height field with the node over Tibet. Lag-correlations between the monsoon trough and the $500 \mathrm{mb}$ geopotential height field in the whole northern hemisphere have suggested that this east-west oscillation is part of the response of the middle and high latitude westerly waves to the northward moving monsoon heat source. That is, the change in the monsoon system from the active to break phase may be considered as the change in the thermodynamical process from the "diabatic limit" to the "advective limit" (Webster, 1981) and vice versa. The response in the higher latitudes reaches its maximum when the heat source approaches to the southern margin of the westerly winds. It is noteworthy to state that this process may involve the change of the basic flow structure via the change of the heat source itself.

The discussion made in this paper is limited in a qualitative sense, since the results were derived preliminarily from some statistical analysis. A synoptic as well as dynamical process of this interaction should be examined more quantitatively in detail. From this viewpoint, the analysis by using the FGGE-MONEX data set is being undertaken.

\section{Acknowledgements}

Some part of the analysis in this paper was made when the author was staying at the Indian Institute of Tropical Meteorology at Pune, India. I am obliged to Sri D.R. Sikka and Dr. S.V. Singh for providing me the data and assisting the data processing. I am grateful to Prof. T.N. Krishnamurti and Mr. J. Sheng, Department of Meteorology, Florida State University for helpful supports and comments on this study. 


\section{References}

Asakura, T. 1955: On the onset of the Baiu and the monsoon. Tenki, 2, 186 (in Japanese)

Bennett, J.R. and J.A. Young, 1971: The Influence of Latitudinal Wind shear upon Large-Scale Wave Propagation into the Tropics. Mon. Wea. Rev., 99, 202-214.

Chang, C.P., 1977: Viscous internal Gravity Waves and Low-Frequency Oscillations in the Tropics. $J$. Atmos. Sci., 34, 901-910.

Charney, J.G., 1969: A further Note on Large-Scale Motions in the Tropics. J. Atmos. Sci., 26, 182-185.

Hirasawa, N., 1986: Variations of Atmospheric Circulation over Asia and the Pacific Associated with the 40-day Oscillation of Indian Summer Monsoon. Master Thesis, Graduate School of Environmental Sciences, Univ. of Tsukuba, 86pp. (in Japanese).

Hoskins, B.J. and D.J. Karoly, 1981: The Steady Linear Response of a Spherical Atmosphere to Thermal and Orographic Forcing. J. Atmos. Sci., 38, 1179-1196.

Huang, R.-H., 1985: The Numerical Simulation of the Three-Dimensional Teleconnections in the Summer Circulation over the Northern Hemisphere. Advances in Atmos. Sci., 2, 82-92.

Julian, P.R. and R.A. Madden, 1981: Comments on a paper by T. Yasunari, "A Quasi-Stationary Appearance of 30 to 40 Day Period during the Summer Monsoon over India". J. Met. Soc. Japan, 59, 435437.

Kalsi, S.R., 1980: On Some Aspects of Interaction between Middle Latitude Westerlies and Monsoon Circulations. Mausam, 31, 305-308.

Krishnamurti, T.N. and D. Subrahmanyam, 1982: The 30-50 Day Mode at $850 \mathrm{mb}$ during Monex. J. Atmos. Sci., 39, 2088-2095.

- , T.N., P.K. Jayakumar, J. Sheng, N. Surgi and A. Kumar, 1984: Divergent Circulations on the 30 to 50 Day Time Scale. J. Atmos. Sci., 42, 364375 .

Kuma, K., 1985: Linear Response of the Global Atmosphere to Thermal Forcing during Northern Summer. J. Met. Soc. Japan, 53, 739-747.

Kurihara, K. and Y. Tsuyuki, 1986: Mechanism of Sub-high Developed over and around Japan during Summer-a Case Study for August, 1984. Abstract of annual meeting, Japan Meteorological Society, 49. (in Japanese).

Lau, K.M. and P.H. Chan, 1986: Aspects of the 4050 day Oscillation during the Northern Summer as Inferred from Outgoing Longwave Radiation. In press in Mon. Wea. Rev.

- and T.J. Phillips, 1986: Coherent Fluctuations of Extratropical Geopotential and Tropical Convection in Intraseasonal Time Scales. In press in J. Atmos. Sci.

Lin, B.D., 1983: The Behavior of Stationary Waves and the Summer Monsoon. J. Atmos. Sci., 40, 11631177.

Lorenc, A.C., 1984: The Evolution of Planetary-Scale
$200 \mathrm{mb}$ Divergent Flow during the FGGE year. Quart. J. Roy. Met. Soc., 110, 427-441.

Madden, R.A. and P.R. Julina, 1971: Detection of a 40-50 day Oscillation in the Zonal Wind in the Tropical Pacific. J. Atmos. Sci., 28, 702-708.

- -1972 : Description of Global-Scale Circulation Cells in the Tropics with a 40-50 Day Period. J. Atmos. Sci., 29, 1109-1123.

Murakami, M., 1984: Analysis of Deep Convective Activity over the Western Pacific and Southeast Asia. Part II. Seasonal and Intraseasonal Variation during the Northern Summer. J. Met. Soc. Japan, 62, 88-108.

Murakami, T., Nakazawa, T. and J. He, 1984: On the 40-50 day Oscillation during the 1979 Northern Hemisphere Summer. Part I. Phase Propagation. J. Met. Soc. Japan, 63, 250-271.

Murakami, T. and T. Nakazawa, 1985: Tropical 45 Day Oscillation during the 1979 Northern Hemisphere Summer. J. Atmos. Sci., 42, 1107-1122.

Pant, P.S., 1983: A Physical Basis for Changes in the Phases of the Summer Monsoon over India. Mon . Wea. Rev., 111, 487-495.

Raman, C.R.V., 1981: Blocking Highs over Eurasia and Their Influence in Breaks in Summer Monsoon over India. Extended Abstracts of Inter. Conf. Sci. Results of Monex, Denpasar, Bali, Indonesia. 1-2126.

Ramaswamy, C., 1962: Breaks in the Indian Summer Monsoon as a Phenomenon of Interaction between the Easterly and the Sub-Tropical Westerly Jet Streams. Tellus, 14, 337-349.

Smith, E.A., 1984: Radiative forcing of the southwest summer monsoon. Ph.D Thesis at Colorado State University.

Stevens, D.E., 1983: On Symmetric Stability and Instability of Zonal Mean Flows near the Equator. J. Atmos. Soc., 40, 882-893.

Suda, K. and T. Asakura, 1955: A Study on the Unusual "Baiu" Season in 1954 by Means of Northern Hemisphere Upper Air Mean Charts. J. Met. Soc. Japan, 33, 233-463.

Tanaka, M., 1983: Interaction Between the ActiveBreak Cycle of the Summer Monsoon and the Circulation in Eurasia and the Western Pacific. J. Met. Soc. Japan, 61, 455-463

Yamagata, T. and Y. Hayashi, 1984: A Simple Diagnostic Model on the 30-50 Day Oscillations in the Tropics. Met. Soc. Japan, 62, 709-7 17.

Yasunari, T., 1979: Cloudiness Fluctuations Associated with the Northern Hemisphere Summer Monsoon. $J$. Met. Soc. Japan, 57, 227-242.

, 1980: A Quasi-Stationary Appearance of 30 to 40 Day Period in the Cloudiness Fluctuations during the Summer Monsoon over India. J. Met. Soc. Japan, 58, 225-229.

, 1981: Structure of an Indian Summer Monsoon System with around 40-Day Period. J. Met. Soc. Japan, 59, 336-354. 
Yeh, T.-C. and Y.-X. Gao, edi., 1979: "Meteorology of the Quinghai-Xizang (Tibetan) Plateau”. Science Press, Beijing, 278pp. (in Chinese)

Webster, P.J., 1981: Mechanisms Determining the Atmospheric Response to Sea Surface Temperature Anomalies. J. Atmos. Sci., 38, 554-571.
1982: Seasonality in the Local and Remote Atmospheric Response to Sea Surface Temperature Anomalies. J. Atmos. Sic., 39, 41-52.

White, G.H., 1982: An Observational Study of the Northern Hemisphere Extratropical Summertime General Circulation. J. Atmos. Sci., 39, 24-40.

\section{北半球夏期におけるモンスーンの長周期変動と偏西風循環の相互作用}

\section{安 成 哲 三}

筑波大学地球科学系

夏季インドモンスーンにみられる季節内長周期変動（30 50日周期振動）と北半球中・高緯度循環と の相互作用を，いくつかの統計的手法を用いて調べた。

高度場の EOF 解析とコンポジット解析は, モンスーンの変動に対応して，チベット高原付近を節と する standing-type の東西振動が，中央アジアから極東域にかけて卓越していることを示す。

モンスーントラフと北半球全域の高度場 $(500 \mathrm{mb})$ との時差相関解析は, この東西振動がモンスーン 熱源に対する中緯度循環の応答として把えられること, モンスーン循環と中・高緯度循環との相互作用 は熱源の中心がヒマラヤ付近に北上した，モンスーン breakに近い時期に極大に達することを示唆させる。

これらの観測的事実に示されるモンスーンと中高緯度との相互作用の機構についての若干の考察も試 みる。 